\title{
PENERAPAN PENDEKATAN CONTEXTUAL TEACHING AND LEARNING UNTUK MENINGKATKAN HASIL BELAJAR IPA SISWA KELAS 4 SDN KESONGO 01 KABUPATEN SEMARANG
}

\author{
Riska Puji Rahayuningtyas, Henny Dwi K
}

Surel: 292013003@ student.uksw.edu

\begin{abstract}
The study aims to improve the learning outcomes of science students grade 4 SDN Kesongo 01. Research methods undertaken are TOD conducted two cycles per cycle consisting of two meetings. The subjects of this study are 4th grade students of SDN Kesongo 01 with 23 students. The results showed an increase in the learning outcomes of grade 4 students SDN Kesongo 01 lesson 2016/2017. With the increase of students' learning outcomes in cycle I, 17 students got the score according to KKM standard $\geq 70(73,9 \%)$ and on cycle II 22 students got value according to KKM standard $\geq 70(95,7 \%)$.
\end{abstract}

Keywords: Contextual Teaching and Learning Approach, Learning Outcomes of Science

\begin{abstract}
ABSTRAK
Penelitian bertujuan untuk meningkatkan hasil belajar IPA siswa kelas 4 SDN Kesongo 01. Metode penelitian yang dilakukan adalah PTK yang dilakukan sebanyak dua siklus setiap siklus terdiri dari dua pertemuan. Subjek penelitian ini adalah siswa kelas 4 SDN Kesongo 01 dengan jumlah siswa 23 orang. Hasil penelitian menunjukkan adanya peningkatan pada hasil belajar siswa kelas 4 SDN Kesongo 01 tahun pelajaran 2016/2017. Dengan peningkatan hasil belajar siswa pada siklus I sebanyak 17 siswa mendapatkan nilai sesuai standar KKM $\geq 70(73,9 \%)$ dan pada siklus II 22 siswa mendapatkan nilai sesuai standar $\mathrm{KKM} \geq 70(95,7 \%)$.
\end{abstract}

Kata Kunci: Pendekatan Contextual Teaching and Learning, Hasil Belajar IPA

\section{PENDAHULUAN}

Ilmu Pengetahuan Alam (IPA) adalah suatu kumpulan teori yang sistematis. Penerapannya secara umum terbatas pada gejala-gejala alam. Lahir dan berkembang melalui metode ilmiah seperti observasi dan eksperimen, serta menuntut sikap ilmiah seperti rasa ingin tahu, terbuka, dan jujur (Trianto 2010:136).
Proses pembelajaran IPA hendaknya dilakukan melalui pemberian pengalaman langsung kepada siswa. Dengan memberikan pengalaman secara langsung kepada siswa, maka akan terlihat semakin jelas bahwa proses pembelajaran IPA lebih ditekankan pada pendekatan keterampilan proses, sehingga siswa dapat menemukan fakta-fakta,

Program Studi PGSD Universitas Kristen Satya Wacana 
membangun konsep-konsep, teoriteori dan sikap ilmiah siswa yang dapat berpengaruh positif terhadap kualitas proses pendidikan maupun produk pendidikan (Trianto 2010:143). Tinggi rendahnya kualitas proses pendidikan dapat ditentukan melalui berhasil tidaknya suatu proses pembelajaran, sedangkan produk pendidikan yang berkualitas dihasilkan melalui proses pembelajaran yang bermutu.

$\begin{array}{lrr}\begin{array}{l}\text { Menurut } \\ \text { menyatakan }\end{array} & \text { bahwa } & \text { proses }\end{array}$
pembelajaran harus diselenggarakan secara interaktif, inspiratif, menyenangkan, dan memberikan ruang yang cukup bagi pengembangan kreatifitas sesuai dengan bakat, minat, dan perkembangan fisik serta psikologi peserta didik. Oleh karena itu, pembelajaran hendaknya didesain sedemikian rupa, sehingga menjadi kegiatan yang menyenangkan. Pembelajaran hendaknya berorientasi pada aktifitas serta pemberian pengalaman langsung kepada siswa.

Namun dalam kenyataannya proses pembelajaran IPA yang diterapkan di sekolah cenderung siswa hanya mendengarkan penjelasan dari guru, sehingga siswa menjadi jenuh dan bosan. Semua aktifitas pembelajaran hanya berpusat pada guru, belum berpusat pada siswa. Siswa diperlakukan sebagai objek dalam pembelajaran, bukan sebagai subjek belajar. Karena pembelajaran bersifat abstrak, siswa sulit memahami apa yang dijelaskan oleh guru. Hal ini yang akan menyebabkan hasil belajar IPA siswa menjadi rendah.

Berdasarkan hasil observasi, pembelajaran IPA di SDN Kesongo 01 lebih sering menggunakan pendekatan pembelajaran yang berpusat pada guru dan tidak mengaitkan konteks materi yang diajarkan dengan lingkungan sekitar siswa. Guru hanya menerangkan materi yang terdapat dalam buku paket kemudian guru meminta siswa untuk mengerjakan soal yang ada di dalam LKS.

Seharusnya guru dapat memfasilitasi atau menciptakan kondisi yang dapat membuat siswa aktif belajar melalui proses penemuan dan memberikan contoh contoh secara nyata atau konkret Hal ini berkaitan dengan karakteristik pembelajaran IPA yang harus dilakukan dengan proses penemuan dan karakteristik peserta didik kelas 4 yang berada dalam tahap operasional konkret, yang mudah merasa bosan dan jenuh ketika dihadapkan dengan proses pembelajaran yang abstrak, sehingga perhatian dan konsentrasi siswa terhadap materi yang disampaikan dalam proses pembelajaran rendah.

Pada saat guru menerangkan materi, siswa cenderung pasif dan tidak memperhatikan karena proses pembelajaran yang membosankan. Terlihat tidak sedikit siswa yang lebih asik dengan kegiatannya sendiri 
seperti: bercerita dengan teman sebangku maupun teman di belakangnya, ada juga siswa yang menggambar saat guru menerangkan materi di depan, bahkan siswa terlihat sering keluar masuk kelas. Hal ini akan berdampak pada pemahaman siswa terhadap materi pelajaran dan mempengaruhi hasil belajar, dimana terlihat dari hasil tes 23 siswa bahwa 16 siswa $(69,5 \%)$ siswa belum memenuhi batas ketuntasan pada standar KKM, dan siswa yang sudah tuntas sesuai standar KKM adalah 7 siswa $(30,5 \%)$.

Berdasarkan masalah tersebut di atas, maka akan dilakukan penelitian tindakan kelas yang berjudul "Upaya Peningkatan Hasil Belajar IPA Siswa Kelas 4 SDN Kesongo 01 Kecamatan Tuntang Kabupaten Semarang Melalui Pendekatan Contextual Teaching And Learning Tahun Pembelajaran 2016/2017'. Contextual teaching and learning adalah sebuah proses pembelajaran yang dimulai dengan sajian yang terkait dengan dunia nyata kehidupan siswa, sehingga akan terasa manfaat dari materi yang akan disampaikan, motivasi belajar muncul, dunia pikiran siswa menjadi konkret, dan suasana menjadi kondusif serta menyenangkan (Suyatno 2009:56). Adapun langkahlangkah pendekatan contextual teaching and learning menurut Rusman (2014:270) adalah:

1. Mengembangkan pemikiran siswa untuk melakukan kegiatan belajar lebih bermakna, apakah dengan cara bekerja sendiri, menemukan sendiri, dan mengkonstruksi sendiri pengetahuan dan ketrampilan baru yang akan dimilikinya.

2. Melaksanakan sejauh mungkin kegiatan inquiry untuk semua topik yang diajarkan.

3. Mengembangkan sifat ingin tahu siswa melalui memunculkan pertanyaan-pertanyaan.

4. Menciptakan masyarakat belajar, seperti melakukan kegiatan kelompok diskusi, tanya jawab, dan lain sebagainya.

5. Menghadirkan model sebagai contoh pembelajaran, bisa melalui ilustrasi,, model, bahkan materi yang sebenarnya.

6. Membiasakan anak untuk melakukan refleksi dari setiap kegiatan pembelajaran yang telah dilakukan.

7. Melakukan penilaian secara objektif yaitu menilai kemampuan yang sebenarnya pada setiap siswa.

Berdasarkan uraian di atas maka dapat dirumuskan maslah sebagai berikut: Apakah ada peningkatan hasil belajar IPA melalui pendekatan Contextual Teaching ang Learning siswa kelas 4 SDN Kesongo 01 Semarang?

Penelitian ini bertujuan untuk mengetahui apakah ada pengngkatan hasil belajar IPA melalui pendekatan Conrextual Teaching and Learning 
siswa kelas 4 SDN Kesongo 01 Semarang.

\section{METODE PENELITIAN}

Sesuai dengan permasalahan yang telah dikemukakan di atas, maka jenis penelitian ini adalah penelitian tidakan kelas (PTK). Menurut Kunandar (2011:44) menyatakan bahwa suatu penelitian tindakan yang dilakukan guru yang sekaligus sebagai peneliti di kelasnya atau bersama-sama dengan orang lain dengan jalan merancang, melaksanakan dan merefleksi tindakan secara kolaboratif dan partisipatif yang bertujuan untuk memperbaiki mutu atau kualitas proses pembelajaran di kelasnya melalui suatu tindakan tetentu dalam suatu sikluspenelitian ini menggunakan model Kemmis dan Mc Taggart. Menurut Kemmis dan Mc Taggart dalam Kunandar (2011:70) menyatakan bahwa penelitian tindakan kelas dilakukan melalui proses yang dinamis dan komplementari yang terdiri dari tiga prosedur tindakan yaitu perencanaan, tindakan dan observasi, dan refleksi. Adapun langkah-langkah penelitian tindakan kelas adalah sebagai berikut ini:

\section{Siklus I}

\section{a. Perencanaan}

Dalam tahap perencanaan ini banyak hal yang harus dipersiapkan secara matang untuk menunjang keberhasilan pelaksanaan Penelitian
Tindakan kelas. Tindakan awal yang harus dilakukan adalah mempersiapkan Rencana Pelaksanaan Pembelajaran (RPP) tentang memahami hubungan antara sumber daya alam dengan lingkungan, teknologi, dan masyarakat serta membuat rancangan evaluasi yang berupa tes tertulis yang digunakan untuk mengetahui sejauh mana hasil yang dicapai setelah tindakan. Dalam tahap perencanaan ini peneliti juga membuat lembar observasi yang digunakan untuk melihat bagaimana situasi pembelajaran berlangsung. RPP Memahami hubungan antara sumber daya alam dengan lingkungan, teknologi, dan masyarakat.

b. Tindakan dan Observasi.

Tindakan atau pelaksanaan adalah implementasi atau pelaksanaan Rencana Pelaksanaan Pembelajaran (RPP) yang telah dibuat dan dilaksanakan dalam proses belajar mengajar didalam kelas. Sedangkan proses pengamatan atau observasi adalah kegiatan pemuatan perhatian terhadap suatu objek dengan menggunakan seluruh alat indera atau juga kegiatan mengamati proses pembelajaran yang telah direncanakan dan disesuaikan dengan kegiatan pembelajaran di dalam kelas. Kegiatan observasi ini dilakukan oleh guru kelas dan dibantu oleh observer atau peneliti. 
Riska Puji Rahayuningtyas: Penerapan Pendekatan..

\section{c. Refleksi}

Refleksi adalah kegiatan yang dilakukan untuk mengevaluasi hasil dari pelaksanaan pembelajaran yang dilakukan. Dalam kegiatan ini hal yang dievaluasi adalah kekurangan dan kelebihan saat kegiatan pembelajaran berlangsung, serta hambatan dari kegiatan yang telah dilakukan, sedangkan hasil tes evaluasi pada siklus I akan dijadikan acuan untuk dijadikan acuan pada pelaksanaan siklus 2 dengan pokok bahasan memahami hubungan antara sumber daya alam dengan lingkungan, teknologi, dan masyarakat.

\section{Siklus II}

Kegiatan pada siklus II dirancang untuk memperbaiki kekurangan pada proses pembelajaran di siklus I, apabila dalam pelaksanaan siklus I belum berhasil dalam pencapaian indikator yang ditentukan maka dalam siklus II hal tersebut akan diperbaiki dan disempurnakan. Pada siklus II juga dibagi kedalam 3 tahap yaitu:

a. Perencanaan

Pada dasarnya kegiatan perencanaan yang dilakukan di siklus II ini masih sama dengan perencanaan pada siklus I. Hal yang diutamakan adalah penyusunan RPP memahami hubungan antara sumber daya alam dengan lingkungan, teknologi, dan masyarakat dan lembar observasi implementasi tindakan pendekatan Contextual Teaching and learning oleh guru dan siswa. Perencanaan siklus II mengacu pada refleksi pembelajaran yang telah dilakukan pada siklus I. Hal yang diutamakan adalah untuk memperbaiki kekurangan pada pembelajaran di siklus I dan untuk meningkatkan hasil belajar siswa.

\section{b. Tindakan dan Observasi.}

Kegiatan yang dilakukan pada tahap ini adalah implementasi dari rencana kegiatan pembelajaran yang telah dibuat. Sama halnya dengan penelitian yang dilakukan pada siklus I, Kegiatan ini juga digunakan sebagai alat untuk mengumpulkan data yang berhubungan dengan tujuan penelitian. Kegiatan inti dilakukan oleh guru kelas dengan berkolaborasi bersama peneliti dan diamati oleh seorang observer.

\section{c. Refleksi}

Kegiatan refleksi yang dilakukan pada siklus II ini sama halnya seperti refleksi pada siklus I. tujuan dari kegiatan refleksi ini adalah sebagai bahan evaluasi tentang kelebihan dan kekurangan pada saat proses pembelajaran, serta hasil tindakan serta hambatan-hambatan yang dihadapi. Sementara itu hasil dari kegiatan refleksi ini akan digunakan untuk menentukan tingkat keberhasilan dari penelitian tindakan yang telah dilakukan.

Demikian tahapan kegiatan akan diulang pada siklus II untuk memperbaiki kekurangan pada proses 
pembelajaran siklus I sehingga semua masalah dapat teratasi. Penelitian ini akan dilakukan di SDN Kesongo 01 Kabupaten Semarang pada siswa kelas 4 Semester II Tahun Pelajaran 2016/2017. Subjek penelitian adalah siswa kelas 4 SDN Kesongo 01 Kecamatan Tuntang Kabupaten Semarang yang berjumlah 23 siswa yang terdiri dari 9 siswa laki-laki dan 14 siswa perempuan. Semua siswa kelas 4 berumur rata-rata $10-12$ tahun.

\section{HASIL DAN PEMBAHASAN}

Pra Siklus

Berdasarkan data yang diperoleh dari hasil observasi yang dilakukan sebelumnya diperoleh daftar hasil belajar siswa pada mata pelajaran IPA sebelum melakukan tindakan atau pra siklus dapat dilihat pada tabel berikut ini:

Tabel

Hasil Belajar IPA Siswa Pra Siklus

\begin{tabular}{|c|c|c|c|}
\hline Nilai & Jumlah Siswa & $\%$ & Keterangan \\
\hline$<70$ & 16 & $69,5 \%$ & Tidak Tuntas \\
\hline$\geq 70$ & 7 & $30,5 \%$ & Tuntas \\
\hline Jumlah & 23 & $100 \%$ & \\
\hline Nilai rata-rata & & 64,04 \\
\hline \multicolumn{2}{|c|}{ Nilai Tertinggi } & & 92 \\
\hline \multicolumn{2}{|c|}{ Nilai Terendah } & & 42 \\
\hline
\end{tabular}

Berdasarkan hasil observasi yang terdapat pada tabel 4.1 terlihat bahwa sebelum diadakan tindakan siswa yang mencapai nilai ketuntasan dalam mata pelajaran IPA hanya terdapat 7 orang siswa dengan nilai $\geq 70$ dengan presentase $30,5 \%$. Sementar ada 16 orang siswa yang belum mencapai nilai ketuntasan pada mata pelajaran IPA dengan nilai $<70$ dengan presentase $69,5 \%$. Dalam hal ini terdapat kesenjangan nilai yang cukup besar antara siswa dengan nilai tertinggi yaitu 92 dengan siswa yang memperoleh nilai terendah yaitu 42 .
Siklus I

Proses pelaksanaan tindakan pada siklus I dilakukan sebanyak 2 kali pertemuan, dengan merencanakan penelitian yang berkolaborasi dengan guru kelas 4 SDN Kesongo 01 untuk menentukan materi pelajaran IPA yang akan diajarkan kepada siswa pada pelaksanaan proses kegiatan siklus I. Setelah itu menentukan kompetensi dasar yang sesuai dengan materi yang akan diajarkan kepada siswa dan membuat rencana pelaksanaan pembelajaran (RPP) dengan 
menggunakan pendekatan cotextual teaching and learnig (CTL).

Siklus I ini dilakukan sebanyak 2 kali pertemuan dengan alokasi waktu $2 \times 35$ menit pada setiap pertemuan. Sebelum kegiatan mengajar dimulai, guru mempersiapkan media yang dibutuhkan untuk proses pembelajaran serta lembar observasi yang digunakan untuk mengamati kegiatan guru dan siswa selama pelaksanaan proses pembelajaran yang menggunakan pendekatan contextual teaching and learning $(C T L)$ berlangsung.

\section{Pertemuan Pertama}

Kegiatan pendahuluan yang dilakukan guru adalah mempersiapkan alat dan media yang akan digunakan dalam proses pembelajaran. Kemudian guru mengajak siswa untuk berdoa menurut agama dan kepercayaan masing-masing, guru juga memeriksa kehadiran siswa dan memberikan apersepsi kepada siswa dengan bercerita tentang sumber daya alam yang terdapat di sekitar lingkungan siswa serta menyampaikan tujuan pembelajaran yang akan dilakukan.

Pada kegiatan inti guru mulai menerapkan pendekatan contextual teaching and learning (CTL) dengan langkah-langkah yaitu guru menggali pengetahuan awal siswa tentang materi yang akan diberikan melalui pertanyaan-pertanyaan seperti "apakah sumber daya alam itu?
Adakah sumber daya alam di sekitar tempat tinggal kita? Apakah ada sumber daya alam disekitar sekolah kita?".

Kemudian guru membagi siswa kedalam 5 kelompok, masingmasing kelompok terdiri dari 3-4 siswa. Setelah semua siswa duduk menurut kelompok masing-masing, guru akan menjelaskan proses pembelajaran yang akan dilakukan hari ini. Setelah guru selesai menjelaskan proses pembelajaran yang akan dilakukan, semua siswa diajak untuk mengamati lingkungan di sekitar sekolah. Setiap kelompok mencatat apa saja yang ditemukan disekitar sekolah baik berupa batu, tanah, tanaman obat yang ditanam di depan kelas, cacing, ulat yang ditemui ditaman, serta 4 ekor ayam yang sedang mencari makan. Setelah pengamatan selesai maka semua siswa kembali kedalam kelas, meskipun waktu untuk pengamatan telah selesai, tetapi masih ada 2 orang siswa yang asik bermain di luar kelas namun setelah dibujuk oleh guru kedua siswa tersebut masuk ke dalam kelas dan berkumpul pada kelompok masing-masing.

Guru mengarahkan dan menggali kembali pengetahuan siswa tentang sumber daya alam yang kemudian setiap kelompok mendiskusikan hasil temuannya dan menggolongkannya ke dalam jenis sumber daya alam (hayati atau non hayati). Ketika siswa melakukan 
diskusi kelompok, tidak semua siswa aktif dalam diskusi.

Ada tiga kelompok, dimana masing-masing kelompok hanya 1-2 siswa saja yang berdiskusi sedangkan siswa yang lain asik berbicara dengan teman lainnya hal ini juga terlihat pada kelompok lain bahkan ada seorang siswa yang berjalan-jalan dan mengganggu teman saat proses diskusi berlangsung sehingga membuat proses pembelajaran berjalan tidak maksimal. Saat proses diskusi berlangsung guru membimbing siswa yang merasa kesulitan dalam menentukan sumber daya alam yang tergolong dalam sumber daya alam hayati maupun non hayati dan menegur siswa yang membuat gaduh kelas. Setelah semua siswa telah selesai mengerjakan tugas kelompok, maka setiap kelompok mempresentasikan hasil kerja kelompok di depan kelas. Setelah ada kelompok yang mempresentasikan hasil kerja kelompoknya maka kelompok lain diberi kesempatan untuk bertanya namun tidak ada satu kelompokpun menanggapi hasil diskusi kelompok yang sedang presentasi. Setelah presentasi kelompok selesai, guru akan membantu siswa dalam menyimpulkan pembelajaran dan meluruskan kesalah pahaman yang terjadi saat kegiatan proses pembelajaran berlangsung. Pada kegiatan akhir guru akan menutup pembelajaran.

\section{Pertemuan Kedua}

Pada kegiatan awal guru membuka pelajaran dengan menyapa siswa dan memberikan salam, tidak lupa guru juga memeriksa kehadiran siswa. Guru memberikan apersepsi dengan mengajak siswa bernyanyi untuk membuat siswa lebih semangat dalam mengikuti proses pembelajaran yang akan berlangsung. Setelah itu guru menyampaikan tujuan pembelajaran yang akan dicapai kemudian guru memberikan pertanyaan kepada siswa tentang pembelajaran yang telah dilakukan sebelumnya, misalnya: apakah masih ada yang ingat tentang materi yang kita pelajari kemarin? Apa yang dimaksud dengan sumber daya alam? Apakah ada yang dapat memberikan contoh sumber daya alam yang ada di sekitar tempat tinggal kalian? Termasuk jenis sumber daya alam apakah sapi?

Pada kegiatan inti guru mulai menerapkan pendekatan contextual teaching and learning (CTL) dengan langkah-langkah yaitu guru membagi siswa kedalam 5 kelompok masingmasing kelompok terdiri dari 3-4 siswa, kelompok yang dibentuk kali ini berbeda dengan kelompok yang dibentuk pada pertemuan sebelumnya.

Setelah dibentuk kelompok siswa duduk bersama kelompok masing-masing. Guru menyiapkan media pembelajaran berupa gambargambar sumber daya alam. Setiap siswa mengambil gambar yang telah 
disediakan oleh guru. Siswa bersama kelompok menempelkan pada kolom jenis yang tersedia (hayati dan non hayati) setelah itu siswa mendiskusikan apa kegunaan sumber daya alam tersebut tetapi masih terlihat hanya 2-3 orang siswa yang mendominasi dalam diskusi kelompok. Setiap kelompok diberikan kesempatan untuk untuk membacakan hasil kerja kelompoknya di depan kelas. Saat ada kelompok yang mempresentasikan hasil kerja kelompoknya maka kelompok lain diberi kesempatan untuk bertanya.

Kemudian guru membimbing siswa dalam membuat rangkuman materi.Siswa mengerjakan soal evaluasi untuk mengukut tingkat pemahaman terhadap materi sumber daya alam yang telah dipelajari bersama dan guru menutup kegiatan pembelajaran.

Hasil tindakan dan observasi yang telah dilakukan pada siklus I pertemuan pertama dan kedua dibuat berdasarkan hasil seluruh rangkaian kegiatan proses pembelajaran yang telah dilakukan oleh guru dan juga siswa pada pembelajaran IPA tentang sumber daya alam dengan menggunakan pendekatan contextual teaching and learning (CTL).

Adapun hasil belajar siswa dan hasil observasi kegiatan guru dan siswa saat proses pembelajaran berlangsung pada siklus I pertemuan pertama dan kedua adalah sebagai berikut:

Tabel

\section{Hasil Belajar IPA Siswa Siklus I}

\begin{tabular}{|c|c|c|c|}
\hline Nilai & Jumlah Siswa & $\%$ & Keterangan \\
\hline$<70$ & 6 & $26,1 \%$ & Tidak Tuntas \\
\hline$\geq 70$ & 17 & $73,9 \%$ & Tuntas \\
\hline Jumlah & 23 & $100 \%$ & \\
\hline \multicolumn{2}{|c|}{ Nilai rata-rata } & \multicolumn{2}{|c|}{75,6} \\
\hline \multicolumn{2}{|c|}{ Nilai Tertinggi } & \multicolumn{2}{|c|}{60} \\
\hline \multicolumn{2}{|c|}{ Nilai Terendah } &
\end{tabular}

Dari data yang diperoleh pada tabel 4.2 dapat dilihat bahwa ketuntasan hasil belajar siswa pada mata pelajaran IPA pada siklus I, terdapat 6 siswa dengan presentase $26,1 \%$ yang masih belum mencapai nilai ketuntasan dengan nilai $<70$ dan terdapat 17 siswa dengan presentase $73,9 \%$ yang telah mencapai nilai ketuntasan dengan nilai $\geq 70$.

Siklus II

Setelah melihat kekurangan dan yang terjadi pada siklus I pertemuan pertama dan kedua maka 
dibuatlah penelitian siklus II dengan perencanaan siklus ini sebagai penyempurna dan juga sebagai kegiatan tindak lanjut dari siklus I yang telah dilaksanakan. Pada proses perencanaan ini masih berkolaborasi dengan guru kelas 4 SDN Kesongo 01 Kecamatan Tuntang Kabupaten Semarang dalam materi sumber daya alam dengan menggunakan pendekatan Contextual Teaching and Learning (CTL).

Sama halnya dengan siklus I, pada siklus II ini akan dilakukan sebanyak dua kali pertemuan dengan masing-masing pertemuan menggunakan alokasi waktu 2 x 35 menit. Sebelum dilakukan penelitian maka terlebih dahulu disampaikan RPP tentang sumber daya alam kepada guru kelas 4 SDN Kesongo 01 Kecamatan Tuntang Kabupaten Semarang agar proses pembelajaran berjalan dengan baik, mempersiapkan alat yang dibutuhkan dalam proses kegiatan pembelajaran, soal evaluasi dan juga mempersiapkan lembar observasi yang digunakan untuk mengamati kegiatan guru dan siswa selam proses pembelajaran dengan menggunakan pendekatan Contextual Teaching and Learning (CTL).

\section{Pertemuan Pertama}

Kegiatan pertemuan pertama pada siklus II dilakukan dengan alokasi waktu 2 x 35 menit. Sebelum memulai proses pembelajaran, guru menyiapkan media yang akan digunakan untuk menunjang proses pembelajaran. Proses pembelajaran yang dilakukan guru adalah mengajak siswa untuk berdoa menurut agama dan kepercayaan masing-masing, memeriksa kehadiran siswa, dan memberikan apersepsi dengan menceritakan sumber daya alam yang ada di lingkungan sekitar sekolah dan menyampaikan tujuan pembelajaran yang akan dilaksanakan. Setelah guru menyampaikan tujuan pembelajaran terlebih dahulu guru memastikan kesiapan siswa dalam mengikuti proses pembelajaran. Guru memberikan pertanyaan kepada siswa seperti: "apakah ada yang pernah melihat bis? Apakah bahan bakar bis tersebut? Apakah bahan bakar tersebut dapat diperbarui atau tidak?" Pada kegiatan inti, guru membagi siswa kedalam 5 kelompok, masing-masing kelompok terdiri dari 3-4 siswa. Setelah semua siswa duduk menurut kelompok masing-masing, guru akan menjelaskan proses pembelajaran yang akan dilakukan hari ini. Setelah guru selesai menjelaskan proses pembelajaran yang akan dilakukan, guru membagikan gambar yaitu gambar gunung, gambar sawah, gambar hutan, gambar laut, dan gambar sungai kepada setiap kelompok. Setiap kelompok menyebutkan apa saja yang ketahui tentang sumber daya alam yang ada di dalam gambar.

Guru mengarahkan dan menggali kembali pengetahuan siswa tentang sumber daya alam yang kemudian setiap kelompok mendiskusikan hasil temuannya dan 
menggolongkannya ke dalam sifat sumber daya alam (dapat diperbarui atau tidak dapat diperbarui). Ketika siswa melakukan diskusi kelompok semua siswa sudah berperan aktif dalam melakukan diskusi walaupun masih ada seorang siswa yang asik menggambar di buku, guru mengamati dan membimbing siswa dalam mengerjakan tugas kelompok.

Setelah semua siswa telah selesai mengerjakan tugas kelompok, maka setiap kelompok mempresentasikan hasil kerja kelompok di depan kelas. Setelah ada kelompok yang mempresentasikan hasil kerja kelompoknya maka kelompok lain diberi kesempatan untuk bertanya. Setelah presentasi kelompok selesai, guru akan membantu siswa dalam menyimpulkan pembelajaran dan meluruskan kesalah pahaman yang terjadi saat kegiatan proses pembelajaran berlangsung. Pada kegiatan akhir guru akan menutup pembelajaran.

2. Pertemuan Kedua

Kegiatan pertemuan kedua pada siklus II dilakukan dengan alokasi waktu 2 x 35 menit. Sebelum proses pembelajaran berlangsung terlebih dahulu guru menyiapkan media yang akan digunakan untuk menunjang proses pembelajaran. Guru mengawali pembelajaran dengan mengajak siswa untuk berdoa sesuai agama dan kepercayaan masing-masing, memeriksa kehadiran siswa, dan memeriksa kesiapan siswa dalam mengikuti proses pembelajaran. Guru memberikan apersepsi dengan mengajak siswa bernyanyi dan guru menanyakan tentang pembelajaran yang telah dilakukan pada pertemuan sebelumnya seperti "apakah masih ada yang ingat tentang materi yang kita pelajari kemari? Berdasarkan sifatnya sumber daya alam dibagi menjadi berapa? Apakah ada yang bisa memberikan contoh sumber daya alam yang dapat diperbarui?". Guru juga menyampaikan tujuan dari pembelajaran yang akan dilakukan pada pertemuan kedua.

Pada kegiatan inti guru mulai menerapkan pendekatan Contextual Teaching and Learning (CTL) dengan langkah-langkah yaitu guru membagi siswa kedalam 5 kelompok sesuai dengan langkah yang ada pada pembelajaran contextual teaching and learning (CTL). Setiap kelompok akan memperoleh lembar kerja dan amplop yang berisi gambar sumber daya alam. Sebelum melakukan kegiatan kelompok terlebih dahulu guru membimbing siswa untuk menyebutkan contoh sumber daya alam berdasarkan sifatnya. Setelah diskusi kelompok selesai dilakukan oleh siswa, maka kegiatan selanjutnya adalah perwakilan setiap kelompok maju ke depan untuk mempresentasikan hasil kerja kelompoknya. Kemudian guru akan memberikan kesempatan kepada siswa untuk menanyakan hal-hal yang kurang dimengerti oleh siswa tentang 
materi sumber daya alam dan meluruskan kesalahan-kesalahan yang terjadi saat diskusi kelompok yang berkaitan dengan materi pembelajaran yang telah dilakukan pada pertemuan kedua di siklus II.

Pada kegiatan akhir pembelajaran guru melakukan refleksi tentang kegiatan pembelajaran yang telah dilakukan dari awal hingga akhir, dan memberikan tindak lanjut tentang materi yang baru saja dibahas bersama siswa.setelah itu siswa mengerjakan soal evaluasi untuk mengukur tingkat pemahaman terhadap materi sumber daya alam yang telah dipelajari bersama kemudian guru menutup kegiatan proses pembelajaran.

Hasil tindakan dan observasi yang telah dilakukan pada siklus II pertemuan pertama dan kedua dibuat berdasarkan hasil seluruh rangkaian kegiatan pembelajaran yang telah dilakukan guru dan juga siswa pada pembelajaran IPA tentang sumber daya alam dengan menggunakan pendekatan Contextual Teaching and Learning (CTL). Adapun hasil belajar siswa dan hasil observasi kegiatan belajar mengajar guru dan siswa pada siklis II pertemuan pertama dan kedua adalah sebagai berikut:

Tabel

Hasil Belajar IPA Siklus II

\begin{tabular}{|c|c|c|c|}
\hline Nilai & Jumlah Siswa & $\%$ & Keterangan \\
\hline$<70$ & 1 & $4,3 \%$ & Tidak Tuntas \\
\hline$\geq 70$ & 22 & $95,7 \%$ & Tuntas \\
\hline Jumlah & 23 & $100 \%$ & \\
\hline \multicolumn{2}{|c|}{ Nilai Rata-rata } & \multicolumn{2}{|c|}{100} \\
\hline \multicolumn{2}{|c|}{ Nilai Tertinggi } & \multicolumn{2}{|c|}{65} \\
\hline \multicolumn{2}{|c|}{ NilaiTerendah }
\end{tabular}

Dari data yang diperoleh pada tabel 4.5 dapat dilihat bahwa ketuntasan hasil belajar siswa pada mata pelajaran IPA pada siklus II, terdapat 1 siswa dengan presentase $4,3 \%$ yang masih belum tuntas dengan nilai $<70$, selain itu terdapat 22 siswa dengan presentase $95,7 \%$ tuntas dengan nilai $\geq 70$.
Perbandingan Hasil Belajar Siswa

Setelah kegiatan pembelajaran dilaksanakan, hasil belajar siswa pada pra siklus, siklus I dan siklus II mengalami peningkatan. Hal ini terlihat dari hasil belajar siswa pra siklus sebanyak 7 siswa yang mendapatkan nilai tuntas $\geq 70$. Setelah dilaksanakan kegiatan pada siklus I hasil belajar IPA siswa kelas 4 SDN Kesongo 01 mengalami peningkatan dengan 17 siswa 
Riska Puji Rahayuningtyas: Penerapan Pendekatan..

mendapatkan nilai tuntas $\geq 70$. memuaskan.hal ini terlihat dari hasil setelah siklus I dilaksanakan peneliti belajar 22 siswa mendapatkan nilai melakukan refleksi untuk mengetahui kekurangan pada siklus I dan tuntas $\geq 70$. Artinya $95,7 \%$ siswa sudah mendapatkan nilai diatas menyempurnakan pada siklus II. Hal ini terlihat ketika hasil belajar siswa pada siklus II menunjukkan indikator pencapaian hasil belajar yang sangat

KKM. Adapun hasil perbandingan hasil belajar siswa pada pra siklus, siklus I dan siklus II dapat dilihat pada tabel berikut:

Tabel 4.6

Perbandingan Hasil Belajar Siswa

\begin{tabular}{|c|c|c|c|c|c|c|c|}
\hline \multirow{2}{*}{ NO } & \multirow{2}{*}{ Nilai } & \multicolumn{2}{|c|}{ Pra Siklus } & \multicolumn{2}{c|}{ Siklus I } & \multicolumn{2}{c|}{ Siklus II } \\
\cline { 3 - 8 } & Jul & $\begin{array}{c}\text { Sml } \\
\text { Siswa }\end{array}$ & $\begin{array}{c}\text { Persentase } \\
(\%)\end{array}$ & $\begin{array}{c}\text { Jml } \\
\text { Siswa }\end{array}$ & $\begin{array}{c}\text { Persentase } \\
(\%)\end{array}$ & $\begin{array}{c}\text { Jml } \\
\text { Siswa }\end{array}$ & $\begin{array}{c}\text { Persentase } \\
(\%)\end{array}$ \\
\hline 1. & Tuntas & 7 & $30,5 \%$ & 17 & $73,9 \%$ & 22 & $95,7 \%$ \\
\hline 2. & $\begin{array}{c}\text { Tidak } \\
\text { Tuntas }\end{array}$ & 16 & $69,5 \%$ & 6 & $26,1 \%$ & 1 & $4,3 \%$ \\
\hline \multicolumn{2}{|c|}{ Jumlah } & 23 & $100 \%$ & 23 & $100 \%$ & 23 & $100 \%$ \\
\hline
\end{tabular}

Dari data yang ada pada tabel 4.6 diketahui adanya peningkatan hasil belajar siswa dari pra siklus, siklus I dan siklus II. Hal ini dapat dilihat dari ketuntasan hasil belajar siswa yang mengacu pada KKM untuk mata pelajaran IPA yakni $\geq$ 70. Pada pra siklus terdapat 7 siswa yang tuntas mata pelajaran IPA dengan presentase $30,5 \%$. Kemudian meningkat di siklus I yang terlihat dari 17 siswa yang tuntas mata pelajaran IPA dengan presentase $73,9 \%$. Dan hasil yang memuaskan terlihat pada siklus II yakni dengan 22 siswa mencapai nilai ketuntasan dalam pelajaran IPA dengan presentase $95,7 \%$. Yang artinya sebagian besar siswa sudah tuntas dalam mata pelajaran IPA.

\section{SIMPULAN}

Berdasarkan hasil penelitian yang telah dilaksanakan pada siklus I dan II, serta pembahasan yang telah diuraikan pada bab IV maka dapat diambil kesimpulan bahwa penerapan pendekatan Contextual Teaching and Learning (CTL) dapat meningkatkan hasil belajar IPA pada siswa kelas 4 SDN Kesongo 01 Kecamatan Tuntang Kabupaten Semarang tahun pelajaran 2016/2017. Hal ini terlihat dari adanya peningkatan hasil belajar siswa pada pra siklus sebanyak 7 orang siswa memperoleh nilai sesuai standar $\mathrm{KKM} \geq 70$ (30,5\%), pada siklus I sebanyak 17 siswa mendapatkan nilai sesuai standar $\mathrm{KKM} \geq 70$ (73,9\%), dan pada siklus II 22 siswa mendapatkan nilai sesuai standar KKM $\geq 70(95,7 \%)$. 
DAFTAR RUJUKAN

Abdurrahman, Mulyono. 2003. Pendidikan Bagi Anak Berkesulitan Belajar. Jakarta: Rineka Cipta.

Arikunto, Suharsimi. 2013. Dasardasar Evaluasi Pendidikan. Jakarta: Bumi Aksara.

Bahri, Aliem. 2012. Penelitian Tindakan Kelas. Makassar: Universitas Muhammadiyah Makasar.

Firman P, I Made Tangkas. 2014. Peningkatan Hasil Belajar IPA Materi

Pengelompokan Makhluk

Hidup Melalui Pendekatan Contextual Teaching and Learning (CTL) Pada Siswa Kelas III SDN 2 Salakan Kecamatan Tinangkung Kabupaten Banggai Kepulauan. Skripsi Universitas Tadulako.

Jumantha, Hamdayana. 2014. Model dan Metode Pembelajaran Kreatifdan Berkarakter.

Bogor: Ghalia Aksara.

Khristina \& Winanto. 2009. Pendidikan Ilmu Pengetahuan Alam SD. Salatiga: Widya Sari.

Majid, Abdul. 2014. Strategi Pembelajaran. Bandung: PT Remaja Rosdakarya.

Muslich, Mansur. 2009.KTSP Pembelajaran Berbasis
Kompetensi dan Kontekstual. Jakarta: PT Bumi Aksara.

Republik Indonesia.2006. Peraturan Mentri Pendidikan

Nasional.Jakarta: Sekertariat Negara.

Rusman. 2014. Model-Model Pembelajaran

Mengembangkan

Profesionalisme Guru.

Jakarta: PT Rajagrafindo

Persada.

Samriani. Penerapan Pendekatan

Contextual Teaching And

Learning (CTL) Dalam

Meningkatkan Hasil Belajar

Siswa Pada Mata Pelajaran IPA di Kelas IV SDN No 3

Siwalempu.Skripsi Universitas Tadulako.

Sanjaya, Wina. 2006. Strategi Pembelajaran Berorientasi Proses Pendidikan. Jakarta: Kencana Prenada Media Group.

Setiawan, Ibnu. 2007.Contextual Teaching and Learning:Menjadikan

Kegiatan Belajar Mengajar Mengasyikkan dan Bermakna. Bandung: MLC.

Slameto, 2010. Belajar dan FaktorFaktor yang Mempengaruhinya. Jakarta: Rineka Cipta.

Slameto.2015. Metodologi Penelitian dan Inovasi Pendidikan. 
Riska Puji Rahayuningtyas: Penerapan Pendekatan..

Salatiga: Satya Wacana
University Press.

Sudjana, Nana. 2004. Penilaian Hasil

Proses Belajar Mengajar.

Bandung: Remaja

Rosdakarya.

Suharsimi. 2014. Prosedur Penelitian

Suatu Pendekatan Praktik.

Jakarta: Rineka Cipta.

Trianto, 2010. Model Pembelajaran

Terpadu: Konsep, Strategi, dan Implementasinya dalam Kurikulum Tingkat Satuan

Pendidikan (KTSP). Jakarta:

Bumi Aksara.

Wardani, Naniek Sulistya, dkk. 2009. Asesmen Pembelajaran SD. Jakarta: Depdiknas. 